\title{
Some Properties of the Clostridium butyricum Group $\beta$-Lactamase
}

\author{
By MICHEL MAGOT \\ Service des Anaérobies, Institut Pasteur, 75724 Paris Cedex 15, France
}

(Received 27 February 1981; revised 13 April 1981)

Clostridium strain CB269, belonging to the butyricum group, produces a $\beta$-lactamase. The substrate profile of this enzyme, as characterized by the microiodometric method, was that of a penicillinase: activity was slightly higher on ampicillin than on benzylpenicillin, while carbenicillin and methicillin were hydrolysed at lower rates. There was poor activity with cephalosporins. The enzyme was excreted during growth, and was inducible to a limited extent by cloxacillin or cefoxitin. The isoelectric point of the enzyme was approximately $4 \cdot 1$.

\section{INTRODUCTION}

$\beta$-Lactamase-mediated resistance to $\beta$-lactam antibiotics is well known in bacteria of various genera (Citri \& Pollock, 1966; Sykes \& Matthew, 1976). Among anaerobic bacteria, $\beta$-lactamases (EC 3.5.2.6) have frequently been found in Gram-negative bacilli of the genus Bacteroides, but it seems that they have rarely been found in Gram-positive bacilli of the genus Clostridium (Del Bene, 1979). In the latter genus, such enzymes have been shown to be present and characterized in only two species, Clostridium ramosum and C. clostridiiforme (previously named Bacteroides clostridiiformis) (Weinrich \& Del Bene, 1976). We recently reported preliminary results for eight strains of clostridia of the butyricum group; these strains, isolated from perinatal infections, were resistant to penicillins and produced $\beta$-lactamases (Magot, 1981). A preliminary study of the substrate profile of the enzymes using the semi-quantitative 'enzymogram' method (Labia \& Barthelemy, 1979) showed that all strains produced the same enzyme, which is of the penicillinase type. One of the strains, CB269, was chosen for the present work to study other properties of the $\beta$-lactamase, including a quantitative characterization of its substrate profile, its excretion and inducibility.

\section{METHODS}

Bacterial strain. Strain CB269 was isolated from stools of a newborn child during an outbreak of necrotizing enterocolitis in a maternity hospital in 1979. This strain was described previously (Magot, 1981); since it had characters intermediate between those of Clostridium butyricum and C. beijerinckii and so did not fit in either species, it was said to belong to the 'Clostridium butyricum group'.

Cultural methods. TYG broth contained $\left(\mathrm{g} \mathrm{I}^{-1}\right)$ : trypticase (BBL), 30; yeast extract (Difco), 20; glucose, 5; sodium thioglycollate, $1 ; \mathrm{pH} \mathrm{7.4;} \mathrm{it} \mathrm{was} \mathrm{supplemented} \mathrm{with} 2 \%(\mathrm{w} / \mathrm{v})$ agar for plating. All cultures were incubated at $37^{\circ} \mathrm{C}$ in anaerobic jars (Baird \& Tatlock) containing an $\mathbf{H}_{2}$ atmosphere and a palladium catalyst.

Antibiotics. The following $\beta$-lactam drugs were obtained commercially: benzylpenicillin (Specia), ampicillin (Totapen; Bristol), carbenicillin (Pyopen; Beecham), cephaloridine (Ceporin) and nitrocefin (both from Glaxo), cefamandole (Lilly), cefotaxime (RU 24 746; Roussel), cefoxitin (Mefoxin; Merck-Sharp-Dohme), methicillin (Penistaph; Bristol), cloxacillin (Cloxypen; Allard).

Crude enzyme preparation. A sample $(50 \mathrm{ml})$ of a culture grown in TYG broth was centrifuged, and the pellet was resuspended in $5 \mathrm{ml}$ of $0.5 \mathrm{M}$-phosphate buffer, $\mathrm{pH} \mathrm{7.0.} \mathrm{The} \mathrm{cells} \mathrm{were} \mathrm{disrupted} \mathrm{by} \mathrm{ultrasonic} \mathrm{treatment} \mathrm{for}$ $15 \mathrm{~min}$ at $0{ }^{\circ} \mathrm{C}$ using a Branson sonifier B15 (30\% time pulses, i.e. approximately $0.3 \mathrm{~s}$ pulses interspersed by $0.7 \mathrm{~s}$ cooling periods). Cell debris was removed by centrifugation $(41000 \mathrm{~g}, 1 \mathrm{~h})$. The crude enzyme extracts were kept at $-20^{\circ} \mathrm{C}$. 
$\beta$-Lactamase assays. Enzymic activity was tested by the microiodometric assay method described by Novick (1962) and modified by Sykes \& Nordström (1972). Assays were done at $30^{\circ} \mathrm{C}$, in $0.1 \mathrm{M}$-phosphate buffer, $\mathrm{pH} 5.9$, with a substrate concentration of $0.4 \mu \mathrm{M}$ : enzyme concentration was adjusted to give total decolorization of the starch-iodine complex (measured at $620 \mathrm{~nm}$ ) in $20-40 \mathrm{~min}$.

Induction experiments. Induction experiments were conduced in an anaerobic glove box (Celster-isotechnie, France). TYG broth $(200 \mathrm{ml})$ prewarmed to $37^{\circ} \mathrm{C}$ was inoculated with $6 \mathrm{ml}$ of a culture of strain CB269 at the end of the exponential growth phase and distributed in tubes $(9.5 \mathrm{ml}$ in each) containing $0.5 \mathrm{ml}$ of antibiotic in distilled water at the appropriate concentration. At this time, the turbidity was approximately 10 Klett units (Klett-Summerson photocolorimeter, filter no. 66), and the bacterial count was $9 \times 10^{6} \mathrm{ml}^{-1}$. These tubes were then incubated at $37^{\circ} \mathrm{C}$, and turbidity was measured every $30 \mathrm{~min}$. A sample of each culture was withdrawn when the turbidity reached 100 and 250 Klett units, and kept in ice. A bacterial count was made, and then these samples were frozen at $-20^{\circ} \mathrm{C}$ until $\beta$-lactamase activities were tested. Where indicated, samples were dialysed for $18 \mathrm{~h}$ against $0.1 \mathrm{M}$-phosphate buffer. pH 5.9. before testing for activity. Total enzymic activities (extracellular plus intracellular) were assayed by the microiodometric method with benzylpenicillin as substrate. Results were obtained as rates of $I_{2}$ decolorization. The value of 100 was arbitrarily given to the rate of decrease of absorbance $\left(A_{620}\right)$ in the control experiment, i.e. the rate of $I_{2}$ decolorization due to the $\beta$-lactamase activity in a culture at a turbidity of 100 Klett units (i.e. $8 \times 10^{7}$ colony-forming units $\mathrm{ml}^{-1}$ ) grown without antibiotic. Rates of decrease in $A_{620}$ in each experiment were converted to values relative to that of the control experiment. The induction rate was defined as: [Experimentally determined relative activity]/[Control relative activity determined in identical conditions (turbidity 100 or 250 Klett units, dialysed or not), but without antibiotics].

Isoelectric focusing. Determination of the isoelectric point of the $\beta$-lactamase was performed in a Pharmacia flat bed electrophoresis apparatus FBE 3000 . Ampholines (LKB) of pI range $3.5-5$ in $6 \%(w / v)$ acrylamide gel were used. The voltage was progressively increased to $15 \mathrm{~V} \mathrm{~cm}^{-1}\left(0.5 \mathrm{~h}\right.$ at $3 \mathrm{~V} \mathrm{~cm}^{-1}, 0.5 \mathrm{~h}$ at $6 \mathrm{~V} \mathrm{~cm}^{-1}$, and so on up to $15 \mathrm{~V} \mathrm{~cm}^{-1}$ which was maintained overnight). Half of the gel was stained with nitrofecin to detect $\beta$-lactamase activity. The non-coloured part of the gel was cut at $5 \mathrm{~mm}$ intervals, and the slices obtained were immersed in $3 \mathrm{ml}$ water and allowed to diffuse for $2 \mathrm{~h}$ (under a vacuum to limit the effect of atmospheric $\mathrm{CO}_{2}$ on $\mathrm{pH}$ ); the $\mathrm{pH}$ was then measured with a Beckman model 3500 digital $\mathrm{pH}$-meter. The $\mathrm{pH}$ of the slice located at the same distance from the origin as the enzymic activity was taken as the isoelectric point of the enzyme.

\section{RESULTS}

\section{Substrate profile of strain CB269 $\beta$-lactamase}

Activity against nine $\beta$-lactam compounds of crude enzyme prepared from an exponential-phase culture was compared by the quantitative microiodometric method (Table 1). The results are in good agreement with those obtained by the semi-quantitative 'enzymogram' method (Magot, 1981): strain CB269 $\beta$-lactamase was of the penicillinase type; it hydrolysed ampicillin more efficiently than benzylpenicillin, while carbenicillin and methicillin were less good substrates. Activity was very low with all cephalosporins, although cephaloridine could be slowly hydrolysed.

\section{Localization of $\beta$-lactamase activity}

To find the location of the $\beta$-lactamase activity, we measured the activity of the supernatant fluid and the pellet obtained by centrifuging cultures, using the microiodometric assay method with benzylpenicillin as substrate. A decrease in total enzymic activity was observed when cells were disrupted by ultrasonic treatment (Table 2). The lack of increase in activity by this treatment showed that there was no permeability barrier (Smith \& Hamilton-Miller, 1963) limiting substrate access to enzyme (crypticity factor approximately 1). The decrease in activity was not due to inactivation of enzyme by ultrasonic treatment since the activity of the supernatant fluids was unaffected by this treatment (Table 2). The decrease was due to a marked diminution of cell-bound activity, but was not a result of elimination of cellular debris since this step was omitted from the experiment. About $25 \%$ of the enzymic activity of cells from an exponential-phase $(8 \mathrm{~h})$ culture was located in the extracellular medium and $71 \%$ remained cell-bound (Table 2$)$. In stationary-phase $(20 \mathrm{~h})$ cultures, about $65 \%$ of the enzymic activity was found in the supernatant fluid. This shows that the enzyme was excreted during growth. 
Table 1. Substrate profile of strain CB269 $\beta$-lactamase

The rate of hydrolysis of each antibiotic is expressed relative to the rate of hydrolysis of benzylpenicillin $(=100)$. The specific activity of the crude enzyme extract with benzylpenicillin as substrate was approximately $0 \cdot 1 \mu \mathrm{kat} \mathrm{ml}^{-1}$.

Antibiotic

Benzylpenicillin
Ampicillin
Carbenicillin
Cephaloridine
Cefamandole
Cefotaxime
Cefoxitin
Methicillin
Cloxacillin

Relative rate of hydrolysis

100
150
47
4
$0 \cdot 1$
$0 \cdot 2$
$0 \cdot 1$
21
$0 \cdot 1$

Table 2. Localization of $\beta$-lactamase activity in strain CB269

The microiodometric assay was performed with benzylpenicillin as substrate. Samples of culture were assayed either directly or after ultrasonic treatment for $15 \mathrm{~min}$ as described in Methods. Enzyme activity, i.e. the rate of decrease of $A_{260}$ ( $\mathrm{I}_{2}$ decolorization), is expressed relative to the activity of the total untreated culture $(=100)$.

$8 \mathrm{~h}$ culture 20 h culture

\begin{tabular}{|c|c|c|c|c|c|c|}
\hline & \multicolumn{6}{|c|}{ Enzyme activities (relative rates of hydrolysis) } \\
\hline & \multicolumn{2}{|c|}{ Total culture } & \multicolumn{2}{|c|}{ Supernatant } & \multicolumn{2}{|c|}{ Pellet } \\
\hline & Untreated & Treated & Untreated & Treated & Untreated & Treated \\
\hline $\begin{array}{l}8 \text { h culture } \\
20 \text { h culture }\end{array}$ & $\begin{array}{l}100 \\
100\end{array}$ & $\begin{array}{l}75 \\
87\end{array}$ & $\begin{array}{l}25 \\
64\end{array}$ & $\begin{array}{l}26 \\
66\end{array}$ & $\begin{array}{l}71 \\
35\end{array}$ & $\begin{array}{l}37 \\
28\end{array}$ \\
\hline
\end{tabular}

Enzyme activities (relative rates of hydrolysis)

\section{Induction experiments}

Enzymic activities of cells from stationary- or exponential-phase cultures grown with or without added antibiotics were measured by the microiodometric method. Four $\beta$-lactam antibiotics were chosen on the basis of their different degrees of sensitivity to strain CB269 $\beta$-lactamase: benzylpenicillin which was efficiently hydrolysed; methicillin which was slowly hydrolysed; and cloxacillin and cefoxitin which were poor substrates (see Table 1). Three concentrations of each antibiotic were tested. Growth curves demonstrated that growth of strain CB269 was hardly affected by the addition of these antibiotics (data not shown). Only drug concentrations approaching the minimum inhibitory concentration slightly modified the growth characteristics: in this case, growth rates during the exponential phase were similar with or without antibiotic, but the lag before growth was increased, probably because of lysis of some of the inoculated cells (the turbidity values after $30 \mathrm{~min}$ incubation had fallen at the highest drug concentrations). The absence of any major modification of growth characteristics is also demonstrated by the bacterial counts which were measured at turbidities of 100 and 250 (Table 3). Although the sampling times were different, since times taken by cultures to reach turbidities of 100 and 250 were longer for cultures with high antibiotic concentrations, the measured bacterial counts were roughly the same in all experiments at the same turbidity value. Bacterial counts obtained at a turbidity of 250 were rather lower than those at a turbidity of 100 , showing that many dead bacteria were present at the beginning of the stationary phase (we did not observe any chain formation at that time). Thus, the $\beta$-lactamase activities measured with every sample could be compared in terms of presence or absence of induction, since variations observed could not be attributed to modifications of growth characteristics.

Induction rates measured at turbidities of 100 or 250 with benzylpenicillin or methicillin were close to $1 \cdot 0$, showing that these antibiotics have no inducing effect on $\beta$-lactamase 


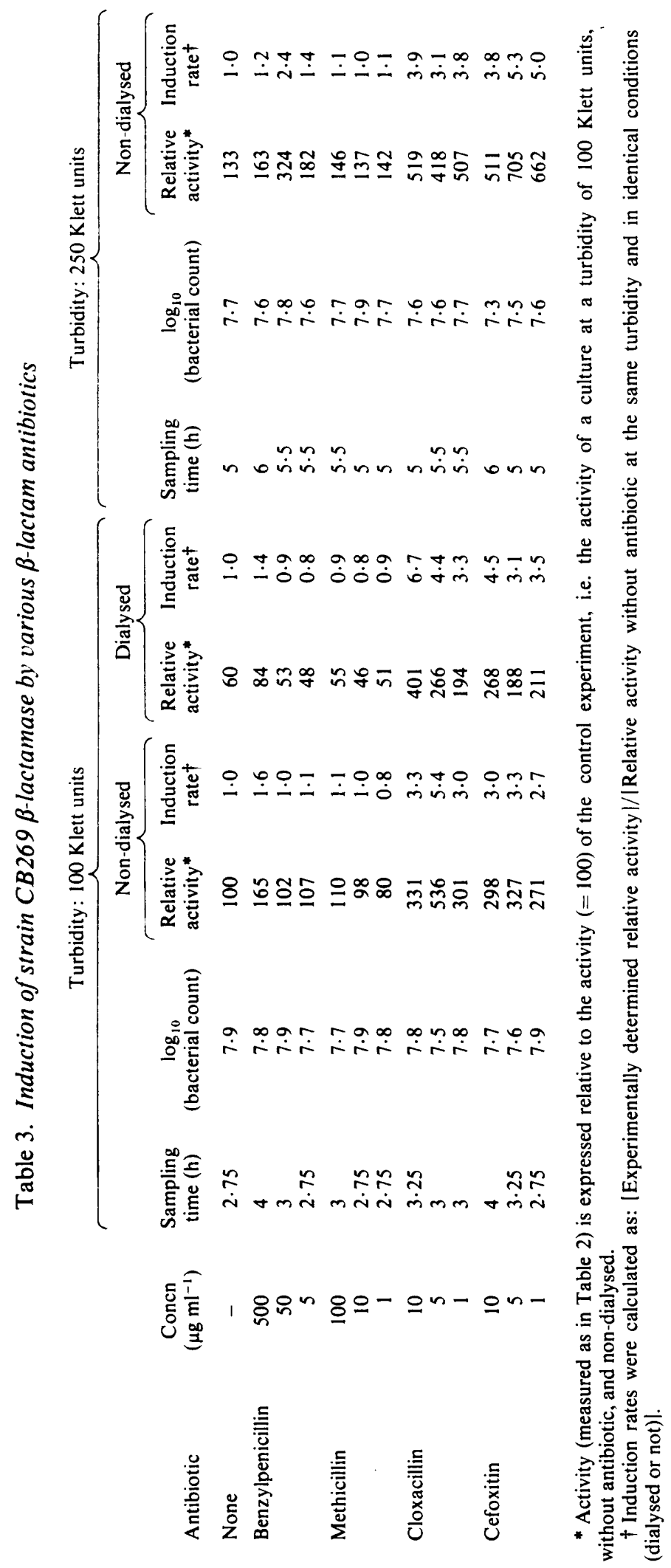


synthesis. Two divergent results (induction rates of 1.6 at a turbidity of 100 with $500 \mu \mathrm{g}$ benzylpenicillin $\mathrm{ml}^{-1}$ and 2.4 at a turbidity of 250 with $50 \mu \mathrm{g} \mathrm{ml}^{-1}$ ) are considered to be aberrant results due to experimental errors, since these values are not consistent with the corresponding results at the other growth time (e.g. the induction rate at a turbidity of 100 with $50 \mu \mathrm{g}$ benzylpenicillin $\mathrm{ml}^{-1}$ was $1 \cdot 0$ ).

Induction rates varying from 3.0 to 5.4 for cloxacillin, and from 2.7 to 5.3 for cefoxitin illustrate a slight induction of CB269 $\beta$-lactamase by these drugs. Measurements with stationary-phase or exponentially growing cells were in good agreement. Because of these low levels of induction, we tested the possibility of a simultaneous inhibitory function of these $\beta$-lactam antibiotics on the enzyme (see Cole, 1979) by eliminating the drug by dialysis of samples before estimating the enzymic activity. The relative activities of exponentially growing cells were lower after dialysis than before, especially in the case of the control experiment and of tests with bacteria induced with benzylpenicillin or methicillin. We have no explanation for these results. Nevertheless, induction rates measured in this experiment support previous results showing that benzylpenicillin and methicillin have no inducing effect, and that a low increase in activity results from the addition of cloxacillin or cefoxitin to culture media. Induction rates by cloxacillin and cefoxitin seemed to be slightly higher after dialysis; this could reflect a low inhibitory effect of these compounds on enzyme activity, but further experiments are needed to corroborate such an observation, because of the low variations noted.

\section{Isoelectric focusing}

Isoelectric focusing of a crude extract of strain CB269 revealed two close bands showing $\beta$-lactamase activity. The $\mathrm{pH}$ of these bands indicated isoelectric points of $4 \cdot 10$ and $4 \cdot 13$.

\section{DISCUSSION}

The quantitative determination of the substrate profile of strain CB269 $\beta$-lactamase has confirmed that this enzyme is of the penicillinase type, as previously reported (Magot, 1981), hydrolysing penicillins very efficiently, while cephalosporins were poor substrates (Table 1 ). This specificity is frequently encountered among Gram-positive $\beta$-lactamases, e.g. those of Bacillus cereus and Staphylococcus aureus (Crompton et al., 1962; Richmond, 1963). It must be noted that the activity observed against cephaloridine was certainly overestimated since hydrolysis of cephalosporin $\mathrm{C}$ and cephaloridine by $\beta$-lactamases is accompanied by the production of two acidic groups (Sabath et al. 1965). For this reason, the microiodometric assay is not considered to be a good method for testing $\beta$-lactamase activity against cephalosporins (Sykes \& Matthew, 1979). Nevertheless, this disadvantage had a negligible effect in the present work because of the very low levels of activity against cephalosporins.

Results obtained by microiodometry were different from those obtained by the enzymogram method for cloxacillin and, to a lesser extent, for cephaloridine: crude enzyme activity had been overestimated for cloxacillin by the enzymogram test, and the low activity on cephaloridine had been missed (Magot, 1981).

The substrate profile of the $C$. butyricum $\beta$-lactamase is very different from that reported for the $C$. ramosum $\beta$-lactamase, but is similar to that of the $C$. clostridiiforme enzyme, although we have no data on hydrolysis of methicillin by this enzyme (Weinrich \& Del Bene, 1976). As C. clostridiiforme was originally thought to be a species of Bacteroides, this enzyme was included in class II of the classification of Gram-negative bacterial $\beta$-lactamases which was recently completed by Sykes \& Smith (1979). This substrate profile similarity for the $C$. butyricum and $C$. clostridifforme enzymes justifies a comparative study of their properties, isoelectric point, molecular weights and sensitivity to $\beta$-lactamase inhibitors, to determine if they are related. Unfortunately, the enzyme of the $C$. clostridiiforme strain could not be focused (M. Matthew, cited by Del Bene, 1979). The $\beta$-lactamase of our strain CB269 had a 
very acidic isoelectric point. The two close bands obtained could be attributed to derivatives of the same molecule.

The study of the localization of enzymic activity in strain CB269 showed that the enzyme is excreted after its synthesis in the cell, since $25 \%$ of the total activity was found in the supernatant fluid after centrifugation of a culture at the beginning of the exponential growth phase, when no cell lysis could be demonstrated microscopically (Table 2 ). The activity in the extracellular medium reached $65 \%$ of the total activity at the end of growth. This increase can be attributed both to persistence of the excretion process and to cell lysis which is evident at the end of exponential growth. $\beta$-Lactamase excretion by Gram-positive bacteria was recognized very early (Duthie, 1944), and the ratios we observed are similar to those described, for instance, in B. cereus (Pollock, 1950); nevertheless, these ratios are probably strain-specific (Dyke, 1979).

Ultrasonic treatment of strain CB269 did not result in an increase of $\beta$-lactamase activity, showing there is no permeability barrier (Smith \& Hamilton-Miller, 1963) limiting access of antibiotic substrates to the enzyme in the $C$. butyricum group. This observation agrees with that made in many other Gram-positive bacteria, like B. cereus (Pollock, 1956), Bacillus licheniformis (Pollock, 1961), S. aureus (Dyke, 1979) or C. ramosum (Weinrich \& Del Bene, 1976). A permeability barrier was nevertheless shown in C. clostridifforme (crypticity factor 2.5) (Weinrich \& Del Bene, 1976). We have no explanation for the decrease of enzymic activity when cells were broken by sonication (Table 2), taking into consideration that this treatment has no deleterious effect on the enzyme itself (Dale, 1979, and Table 2).

Since Duthie first reported inducibility of $\beta$-lactamase in Bacillus subtilis (Duthie, 1944), it has been shown that this property is very widespread among Gram-positive bacteria, although some strains produce $\beta$-lactamase constitutively (Abraham \& Waley, 1979). Induction rates vary from 20 (Duthie, 1944) to 300 (Pollock, 1957) according to the species and experimental conditions. We have not observed such high induction rates with $C$. butyricum strain CB269, whatever the conditions used. Nevertheless, low induction rates $(2.7$ to 5.4) were obtained when bacteria were incubated with cloxacillin or cefoxitin. These low values were not markedly increased by dialysis of samples, in order to remove bound inducing agents, before testing the enzymic activity.

To our knowledge, low induction rates (below 10) have only been reported in the case of the $C$. clostridiiforme enzyme (Weinrich \& Del Bene, 1976); in this case, a twofold induction was obtained when using benzylpenicillin as inducing agent, and an 8-to 10-fold induction with cefoxitin. These data emphasize the need for a comparison of the two enzymes. From that point of view, induction experiments done in exactly the same conditions would be of great interest. In the case of the $C$. clostridiiforme enzyme, there was an optimal inducing concentration of drug, which was 0.75 of the minimum inhibitory concentration. The idea of an optimal inducing concentration of drug was not clearly apparent from our results for strain CB269 $\beta$-lactamase.

The author wishes to thank Dr E. Collatz for helpful discussion.

\section{REFERENCES}

Abraham, E. P. \& Waley, S. G. (1979). $\beta$-Lactamases from Bacillus cereus. In Beta-Lactamases, pp. 311-338. Edited by J. M. T. Hamilton-Miller \& J. T. Smith. New York: Academic Press.

Citri, N. \& Pollock, M. R. (1966). The biochemistry and function of $\beta$-lactamase (penicillinase). Advances in Enzymology 28, 237-323.

Cole. M. (1979). Inhibition of B-lactamases. In Beta-Lactamases, pp. 205-290. Edited by J. M. T. Hamilton-Miller \& J. T. Smith. New York: Academic Press.
Crompton, B., Jago, M., Crawford, K., Newton, G. G. F. \& Abraham, E. P. (1962). Behaviour of some derivatives of 7-amino cephalosporanic acid and 6-aminopenicillinanic acid as substrates, inhibitors and inducers of penicillinases. Biochemical Journal 83, 52-63.

Dale, J. W. (1979). Purification of $\beta$-lactamases. In Beta-Lactamases, pp. 73-98. Edited by J. M. T. Hamilton-Miller \& J. T. Smith. New York: Academic Press.

Del Bene, V. E. (1979). Enzymatic and genetic basis 
for $\beta$-lactam resistance in anaerobic bacteria. In Beta-Lactamases, pp. 443-464. Edited by J. M. T. Hamilton-Miller \& J. T. Smith. New York: Academic Press.

DUTHIE, E. S. (1944). The production of penicillinases by organisms of the subtilis group. British Journal of Experimental Pathology 25, 96-100.

DYKe, K. G. H. (1979). $\beta$-Lactamases of Staphylococcus aureus. In Beta-Lactamases, pp. 291-310. Edited by J. M. T. Hamilton-Miller \& J. T. Smith. New York: Academic Press.

LABIA, R. \& BARTHELEMY, M. (1979). L'enzymogramme des $\beta$-lactamases: adaptation en gel de la méthode microiodométrique. Annales de Microbiologie 130B, 295-304.

MAGot, M. (1981). Resistance aux pénicillines dûe à la production d'une béta-lactamase chez les Clostridium du groupe butyricum. Comptes rendus hebdomadaire des séances de l'Académie des Sciences, série III 292, 285-287.

Novick, R. P. (1962). Micro-iodometric assay for penicillinase. Biochemical Journal 83, 236-240.

Pollock, M. R. (1950). Penicillinase adaptation in Bacillus cereus: adaptative enzyme formation in the absence of free substrate. British Journal of Experimental Pathology 31, 739-753.

Pollock, M. R. (1956). The cell-bound penicillinase of Bacillus cereus. Journal of General Microbiology 15, 154-169.

Pollock, M. R. (1957). The activity and specificity of inducers of penicillinase production in Bacillus cereus, strain NRRL569. Biochemical Journal 66, 419-428.

Pollock, M. R. (1961). The measurement of the liberation of penicillinase from Bacillus subtilis. Journal of General Microbiology 26, 239-253.

RichMOND, M. H. (1963). Purification and properties of the exopenicillinase from Staphylococcus aureus. Biochemical Journal 88, 452-459.

Sabath, L. D., Jago, M. \& Abraham, E. P. (1965). Cephalosporinase and penicillinase activities of a $\beta$-lactamase from Pseudomonas pyocyanea. Biochemical Journal 96, 739-752.

Smith, J. T. \& Hamilton-Miller, J. M. T. (1963). Differences between penicillinases from gram-positive and gram-negative bacteria. Nature, London 197, 976-978.

SyKes, R. B. \& MATTHEw, M. (1976). The $\beta$-lactamase of gram negative bacteria and their role in resistance to $\beta$-lactam antibiotics. Journal of Antimicrobial Chemotherapy 2, 115-157.

Sykes, R. B. \& MATTHEW, M. (1979). Detection, assay and immunology of $\beta$-lactamase. In BetaLactamases, pp. 17-50. Edited by J. M. T. Hamilton-Miller \& J. T. Smith. New York: Academic Press.

SYKeS, R. B. \& NoRdSTRÖM, K. (1972), Microiodometric determination of $\beta$-lactamase activity. Antimicrobial Agents and Chemotherapy 1, 94-99.

SyKes, R. B. \& SMITH, J. T. (1979). Biochemical aspects of $\beta$-lactamases from gram-negative organisms. In Beta-Lactamases, pp. 369-402. Edited by J. M. T. Hamilton-Miller \& J. T. Smith. New York: Academic Press.

Weinrich, A. E. \& Del Bene, V. E. (1976). Beta-lactamase activity in anaerobic bacteria. Antimicrobial Agents and Chemotherapy 10, 106-111. 